(The 3rd ICBS-2013)

\title{
PATTERNS OF Coptotermes sp. TERMITE ATTACK ON Shorea leprosula Miq IN KHDTK SEBULU, EAST KALIMANTAN
}

\author{
Andrian Fernandes and Ngatiman \\ Dipterocarps Research Centre, Samarinda, East Kalimantan \\ Email: af.andrian.fernandes@gmail.com
}

\begin{abstract}
Red meranti (Shorea leprosula Miq) as a major commercial timber has been widely planted in Dipterocarp forests. Coptotermes sp. termite often attacks S. leprosula Miq to its death, but the attack patterns are unknown. This research aims to get data on the frequency, intensity, and patterns of Coptotermes sp. attack in KHDTK Sebulu, East Kalimantan. Methods used were observation, recording, and mapping on S. leprosula Miq trees attacked by termites in KHDTK Sebulu. The results showed that the frequency of termite attacks on S. leprosula Miq in KHDTK Sebulu was $6.4-30.5 \%$ and termite attacks intensity was $4.7-22.1 \%$. Termite attack patterns tended to spread and were followed by the formation of the nest to produce colonies.
\end{abstract}

Key words : S. Leprosula Miq plant, Coptotermes sp.,attack frequency, attack intensity, attack pattern.

\section{INTRODUCTION}

Termites are the most problematic pests in the plant kingdom. Termites are excellent decomposers of dead wood and other sources of cellulose from plants (Verma et al., 2009). In the field, Coptotermes termites attack plantation forest. Shorea leprosula Miq as a valuable species in plantation forest (Subiakto \& Parthama, 2007) are also attacked by termites. Termite attack symptoms in S. leprosula Miq is the crust of soil covering tree trunks up to several meters from the ground. This termite attack occurrs on trees that are both alive and dead, but the attack patterns are unknown. This research aims to get data on the frequency, intensity, and patterns of Coptotermes sp. termite attack in the forest research (KHDTK) Sebulu, East Kalimantan.

\section{MATERIALS AND METHODS}

The study was conducted by making 4 plots in the Forest Area for Special Purpose (KHDTK) Sebulu, Kutai Kertanegara Distric, East Kalimantan. Each 0.3 ha plot extent, interplot bounded by $2 \mathrm{~m}$ wide path. Observation of termite attacks on $\mathrm{S}$. Leprosula was conducted by observing each tree in the plot based on the score as presented in Table 1. The patterns of termite attacks on S. leprosula were then mapped. 
Table 1. Determination score of termite attack on trees

\begin{tabular}{|c|c|c|}
\hline Tree condition & criteria & Score \\
\hline Not affected & No termite attack & 0 \\
\hline & Attacked the relatively narrow tree marked with the soil & \\
\hline Light affected & $\begin{array}{l}\text { crust on tree trunks or soil crust form the grooves found on } \\
\text { rooting and stem }\end{array}$ & 1 \\
\hline Medium affected & $\begin{array}{l}\text { The affected part of the tree is relatively medium area, } \\
\text { with the soil crust characterized by ground on tree trunks } \\
\text { or soil crust that forms around a tree trunk and closed the } \\
\text { half of the diameter of the trunk }\end{array}$ & 2 \\
\hline Heavy affected & $\begin{array}{l}\text { The affected part of the tree is relatively wide area, with } \\
\text { the soil crust characterized by ground on tree trunks or } \\
\text { soil crust has formed close trunk }\end{array}$ & 3 \\
\hline Death & $\begin{array}{l}\text { Soil crust on the trunk or soil crust formed already covered } \\
\text { the entire tree trunks, tree leaves was fallen and no signs } \\
\text { of life }\end{array}$ & 4 \\
\hline
\end{tabular}

Sources : Mardji (2000) with modification

The attack frequency $(F)$ was calculated using the formula (Mardji, 2003) as follows:

$$
F=\frac{X}{y} \times 100 \%
$$

Remarks:

$\mathrm{F}=$ attack frequency $(\%)$

$X=$ numbers of attacked plants

$y=$ numbers of observed plants

The attack intensity of (I) was calculated using the formula according to Mardji (2000) that was modified as follows:

$$
I=\frac{X_{1} y_{1}+X_{2} y_{2}+X_{3} y_{3}+X_{4} y_{4}}{x_{4}} \times 100 \%
$$

Remarks :

$$
\begin{array}{ll}
X_{1} & =\text { number of observed plants } \\
X_{1} & =\text { number of light damaged plants (skor } 1) \\
X_{2} & =\text { number of moderately damaged plants (skor 2) } \\
X_{3} & =\text { number of heavy damaged plants (skor } 3) \\
X_{4} & =\text { number of death plants (skor } 4 \text { ) } \\
y_{1}-y_{4} & =\text { grades } 1 \text { to } 4 \text { of each of the plants showing symptoms of a mild attack to } \\
& \text { death (no sign of life). }
\end{array}
$$


To describe the overall condition of plants in research area due to termite attack can be discovered based on criteria according to Mardji (2003) can be seen in Table 2.

Table 2. Determining condition of the plants based on termites attack

\begin{tabular}{ll}
\hline Attack intensity (\%) & Plants condition \\
\hline $0-1$ & Healthy \\
$>1-25$ & Lightly damaged \\
$>25-50$ & Moderately damaged \\
$>50-75$ & Heavily damaged \\
$>75-100$ & Very heavily damaged \\
\hline
\end{tabular}

\section{RESULT AND DISCUSSION}

Coptotermes sp. termites attack on S. leprosula marked on the ground in the presence of soil crust on the trunk of the tree, if the tree trunk is covered by a crust of soil, then the plant will eventually die. Coptotermes sp. attacked living and dead trees. According to Natawiria (1989), the characteristics of Coptotermes sp. attack was crust bark ground cover up to several meters from the ground. Termites eat cellulose in trunk, so trees are easily broken or uprooted when exposed to the wind. The number and frequency of Coptotermes termites attack in S. leprosula in KHDTK Sebulu is presented in Table 3.

Tabel 3. Number and frequency of Coptotermes termites attack in S. leprosula in KHDTK Sebulu.

\begin{tabular}{|c|c|c|c|c|c|c|}
\hline Plot & $\begin{array}{l}\text { Spacing } \\
\text { (m) }\end{array}$ & $\begin{array}{l}\text { Number } \\
\text { of plants }\end{array}$ & $\begin{array}{l}\text { Number of } \\
\text { plants which } \\
\text { attacked by } \\
\text { termites }\end{array}$ & $\begin{array}{l}\text { Attacked } \\
\text { frequency } \\
(\%)\end{array}$ & $\begin{array}{l}\text { The number of } \\
\text { plants that die } \\
\text { from termite } \\
\text { attack }\end{array}$ & $\begin{array}{l}\text { Death } \\
\text { frequency } \\
(\%)\end{array}$ \\
\hline 1 & $1 \times 1$ & 1.080 & 0 & 0 & 0 & 0 \\
\hline 2 & $\begin{array}{l}1,4 x \\
1,4\end{array}$ & 477 & 31 & 6,4 & 15 & 3,1 \\
\hline 3 & $2 \times 2$ & 275 & 0 & 0 & 0 & 0,0 \\
\hline 4 & $3 \times 3$ & 121 & 37 & 30,5 & 17 & 14,0 \\
\hline
\end{tabular}

Table 3 shows that the frequency of termite attack on plot 2 was $6.4 \%$ and 4 plot was $30.5 \%$. $69.3 \%$ of the tropical rain forest trees infested by termites Coptotermes Amazon with a mortality frequency of $14.4 \%$ (Apolinario and Martius, 2004). Termites that attacked $S$. leprosula ate cellulose in the trunk until the tree died. Based on the resistance of wood against termites attack, $S$. leprosula belongs to resilience grade wood is very susceptible to termite attack $C$. curvignathus and other species such as Pinus and Acacia mangium (Rudi et al., 1999).

Layout sketch of the $S$. leprosula spacing of $1.4 \mathrm{~m} \times 1.4 \mathrm{~m}$ (plot 2) and $3 \mathrm{~m} \times 3 \mathrm{~m}$ (plot 4) that were attacked by Coptotermes sp. termite in KHDTK Sebulu can be seen in the Appendix 1 and 2. The amount and intensity of termite attack on $S$. leprosula in KHDTK Sebulu can be seen in Table 4. 
Table 4. The amount and intensity of termite attack on S. leprosula in KHDTK Sebulu

\begin{tabular}{lllll}
\hline Plot & $\begin{array}{l}\text { Spacing } \\
(\mathrm{m})\end{array}$ & $\begin{array}{l}\text { Number of } \\
\text { plants }\end{array}$ & $\begin{array}{l}\text { Amount of termite } \\
\text { attack }\end{array}$ & $\begin{array}{l}\text { Intensity of termite } \\
\text { attack (\%) }\end{array}$ \\
\hline 1 & $1 \times 1$ & 1.084 & 0 & 0,0 \\
2 & $1,4 \times 1,4$ & 477 & 31 & 4,7 \\
3 & $2 \times 2$ & 275 & 0 & 0,0 \\
4 & $3 \times 3$ & 121 & 37 & 22,1 \\
\hline
\end{tabular}

Table 4 shows that the intensity of the termite attack on plot 2 and 4 were $4.7 \%$ and $22.1 \%$, respectively. Both intensity are considered light damage. In general, the loss because of termite attack was high, ranging from 19 to $80 \%$ of the saplings (Nair \& Varma, 1985). In addition, termite attack is slow but sure, Coptotermes sp termite often attacks $S$. leprosula to its death. Then the termites will continue to attack from one tree to another in the surrounding area when no control is performed.

The presence of termite attack on plants with primary nest termite mound of soil in the form attached to the tree trunk. The primary termite nest was the queen produce termite colony. Hasan (1986), species of subterranean termites, in addition to the primary nest in the ground, the wood is a secondary nest to hatch and hide themselves from predatory insects, so that the diameter of the tree which provides an opportunity for active termites in taking food from the tree. Patterns of termite attacks tend to spread from the primary nest to the nearby trees (Black \& Okwakol, 1997).

Environmental conditions in the understory of $S$. leprosula in KHDTK Sebulu were good enough for termites to breed. It was based on the observations of temperature and humidity environments, which ranged from 20.2 to $28.0^{\circ} \mathrm{C}$ and 80.0 to $90.1 \%$. According to Nandika et al. (2003), subterranean termites like Coptotermes, Macrotermes, Odontotermes, and other species require humidity between $79 \%$ and $90 \%$ and an optimum temperature of 15 $38^{\circ} \mathrm{C}$ for their growth and activity. Temperature and humidity were factors that jointly affected termite activity. Environmental changes caused changes in the development and behavior of termite activity.

\section{CONCLUSION}

Termites (Coptotermes sp.) in meranti (S. leprosula) in KHDTK Sebulu could result in death. Termite attack was characterized by the presence of soil crust that covered most or all of the tree trunk. Termite nest was a place to produce termite colony. The more termite attack found, there was a tendency of attacks is increasing.

\section{REFERENCES}

Apolinario, F.E., and C. Martius. 2004. Ecological Role of Termites (Insecta, Isoptera) in Tree Trunks in Central Amazonian Rain Forests. Forest Ecology and Management Journal. Vol. 194 : 23-28.

Black, H.I.J., and M.J.N. Okwakol. 1997. Agricultural Intensification, Soil Biodiversity and Agroecosystem Function in The Tropics : The Role of Termites. Applied Soil Ecology Journal. Vol. 6 : 37-53. 
Hasan, T. 1986. Beberapa teknik pengendalian rayap di Indonesia. Ghalia Indonesia, Jakarta.

Mardji, D. 2000. Penuntun pratikum penyakit hutan. Fakultas Kehutanan Universitas Mulawarman, Samarinda.

Mardji, D. 2003. Identifikasi dan penanggulangan penyakit pada tanaman Kehutanan. Pelatihan Bidang Perlindungan Hutan di PT ITCI Kartika Utama, Samarinda. H 62 - 87.

Nair, K.S.S., and R.V. Varma. 1985. Some Ecological Aspects of the Termite Problem in Young Eucalypt Plantations in Kerala, India. Forest Ecology and Management Journal. Vol. 12 : 287-303.

Nandika, D.R. Yudi, and F. Diba. 2003. Rayap, biologi dan pengendaliannya. Muhammadiyah Surakarta Press, Surakarta.

Natawiria, D. 1989. Teknik pengenalan hama hutan tanaman industri. Informasi Teknik No. 4. Pusat Penelitian dan Pengembangan Hutan, Bogor.

Rudi, D., R.C. Nandika, Tarumingkeng dan D. Darusman 1999. Preferensi makan rayap tanah Coptotermes curvignathus Holungren (Isoptera, Rhinotermitidae) terhadap delapan jenis kayu bangunan. Prosiding Mapeki (Masyarakat Peneliti Kayu Indonesia), Yogyakarta.

Verma, M., S. Sharma, and R. Prasad. 2009. Biological Alternatives for Termite Control : A Review. International Biodeterioration and Degradation Journal. Vol. 63 : 959-972.

Appendix 1. Layout sketch of the S. Leprosula spacing of $1.4 \mathrm{~m} \times 1.4 \mathrm{~m}$ which attacked by termites in KHDTK Sebulu 